\title{
Management of Ramularia leaf spot on cotton using integrated control with genotypes, a fungicide and Trichoderma asperellum
}

\author{
Juliano Cesar da Silva a, Nelson Dias Suassuna ${ }^{\text {b, Wagner Bettiol }}{ }^{\text {c, * }}$ \\ a Universidade Estadual Paulista “Julio de Mesquita Filho", FCA/Campus Botucatu, 18603-970, Botucatu, SP, Brazil \\ b Embrapa Cotton, CP 174, 58428-095, Campina Grande, PB, Brazil

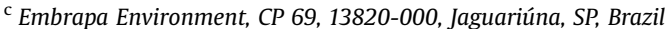

\section{A R T I C L E I N F O}

\section{Article history:}

Received 25 August 2016

Received in revised form

21 November 2016

Accepted 4 December 2016

Available online 23 December 2016

\section{Keywords:}

Cotton varieties

Gossypium hirsutum

Ramularia areola

Ramularia leaf spot

Biological control

\begin{abstract}
A B S T R A C T
Ramularia leaf spot, caused by Ramularia areola, is responsible for premature defoliation of cotton, resulting in potential reductions in yield. The objective of this study was to evaluate integrated control using genotypes, a fungicide and Trichoderma asperellum to manage Ramularia leaf spot on cotton. In the greenhouse, the resistance of eighteen genotypes was evaluated with two isolates of $R$. areola (IMA 244 and IMA 237). In field, the severity of Ramularia leaf spot was evaluated on cotton genotypes CNPA MT 2009-1381, CNPA GO 2007-419, BRS 293, BRS 372, CNPA GO 2008-1265 and FMT 701 treated or untreated with a fungicide in Primavera do Leste, MT, Correntina, BA, and Santa Helena de Goiás, GO, during the 2011-2012 season. The varieties BRS 293 and BRS 372 were sprayed with a fungicide or Trichoderma in Sapezal, MT, during the 2012-2013 season, and the disease severity and fiber yield were evaluated. Significant interactions were detected between Ramularia isolates and cotton genotypes; the lowest disease severity was observed with IMA CD 05-8276 and CNPA GO 2007-419 genotypes. In the field tests, the lowest disease severity was with variety BRS 372 and the highest was with BRS 293, when grown in two different regions. The chemical fungicide and $T$. asperellum both reduced the disease severity in cotton varieties BRS 372 and BRS 293; however, yields were not significantly affected. In conclusion, an integrated strategy with the management tools of resistant varieties, fungicides and biocontrol agents should be used to control Ramularia leaf spot on cotton.
\end{abstract}

() 2016 Elsevier Ltd. All rights reserved.

\section{Introduction}

Ramularia leaf spot, caused by Ramularia areola G. F. Atk., teleomorph Mycosphaerella areola Ehrlich \& F.A. Wolf, is the most important disease of cotton (Gossypium hirsutum) in Brazil (Suassuna and Coutinho, 2007). Symptoms typically are primarily on the lower parts of the plant and are characterized by white-blue lesions on the under surface of leaves from which the fungus develops white or yellow powdery sporulation (Bell, 1981). Ramularia areola infects cotton leaves causing premature defoliation and a reduction in photosynthetic capacity of the plants, with a consequent reduction in the yield potential of different varieties. Aquino et al. (2008a) found that the disease reduced fiber yield $49 \%$ in Brazil. According to Rathaiah (1976), Ramularia leaf spot must be

\footnotetext{
* Corresponding author.

E-mail addresses: wagner.bettiol@embrapa.br, wagnerbettiol@gmail.com (W. Bettiol).
}

managed, and varieties resistant to the pathogen are the cheapest and most efficient method for disease control. Cia et al. (2009) evaluated 18 cotton genotypes; 61\% of the genotypes were moderately or highly susceptible and $29 \%$ were moderately resistant to Ramularia. In glasshouse conditions, Zandoná et al. (2012) found that a single dominant gene governed the resistance to $R$. areola strain 44 in the genotypes CNPA BA 2003-2059 and FMT 02102996. Additionally, Aurangabadkar et al. (1981), Mukewar and Mayee (2001) and Mukewar et al. (1995) demonstrated that some cotton genotypes have immunity to $R$. areola.

Currently, chemical fungicides are the primary method for control of Ramularia leaf spot in Brazil (Suassuna and Coutinho, 2007; Aquino et al., 2008a). Although Ramularia leaf spot is controlled efficiently with fungicides, disease control alternatives must be developed for integrated management. Because biopesticides are an alternative to sustain high production with low ecological impact, research in the development of biocontrol is currently expanding exponentially (Pérez et al., 2015), with Trichoderma-based products the most important biofungicides used 
worldwide (Lorito et al., 2010). According to Bettiol et al. (2014), Trichoderma is the most important commercialized biocontrol agent and is it used for control of soilborne, foliar and postharvest diseases in several crops (Harman et al., 2004; Harman, 2006; Woo et al., 2006). This biocontrol agent protects plants by producing antibiotics and enzymes, promoting plant growth, and inducing plant defenses, in addition to increasing competition for nutrients (Hermosa et al., 2012). Biofungicides efficiently control plant diseases and are environmentally safe; however, although use is expanding annually, the adoption by growers remains limited (Bettiol, 2011). On cotton, the foliar application of Trichoderma viride reduces the severity of Ramularia leaf spot when sprayed alone or in combination with a fungicide (Duarte et al., 2007; Freitas et al., 2007).

The aim of this study was to evaluate the integrated management of Ramularia leaf spot on cotton with genotypes, a fungicide and T. asperellum.

\section{Materials and methods}

\subsection{Inoculum of $R$. areola}

Dr. Rafael Galbieri (Instituto Matogrossense do Algodão - IMA) provided isolates IMA 244 and IMA 237 of $R$. areola. The isolates were grown on $20 \mathrm{~mL}$ of malt extract-agar $2 \%$ in plates (polystyrene, $90 \times 10 \mathrm{~mm}$ ), which were incubated for $7 \mathrm{~d}$ at $25 \pm 2{ }^{\circ} \mathrm{C}$ with $12 \mathrm{~h}$ of fluorescent light and $12 \mathrm{~h}$ of darkness. The conidia of $R$. areola were suspended in Tween 80 solution with sterile distilled water $(0.01 \% \mathrm{v} / \mathrm{v})$, and the suspensions were filtered to remove spore aggregates. Conidial concentrations were adjusted by hemocytometer, and dilutions were prepared with sterile Tween 80 solution $(0.01 \% \mathrm{v} / \mathrm{v})$ for inoculation of foliar tissues.

\subsection{Assessment of cotton genotypes for Ramularia leaf spot management}

Ten seeds of cotton genotypes LD CV03, BRS 336, IAC 08-2031, IMA CD 03-1661, IPR Jataí, DP 604 BG, Nuopal, FM 910, PRGOA 03231-04, BRS 2080, IAC 08/90, LD CV 12, FM 993, FMT 709, IMA CD 05-8276, FMT 705, CNPA GO 2006-174 and CNPA GO 2007-419 were sown in $1 \mathrm{~L}$ pots containing soil (red dystroferric latosol-oxisol with clayey texture) and substrate (composted pine bark) (10:1). After emergence, two of the most vigorous seedlings were selected and maintained in a screen house (25\% light reduction) with a sprinkler system. The seedlings were watered twice daily. Cotton plants were inoculated with a suspension of $1 \times 10^{6}$ conidia $\mathrm{mL}^{-1}$ of $R$. areola isolates IMA 244 and IMA $23745 \mathrm{~d}$ after sowing; the suspensions were sprayed (1.5 L Pre-Compressed hand sprayer - Tramontina-78610150, Carlos Barbosa, RS) on leaves until runoff. Disease severity was evaluated 15, 20, 30 and $40 \mathrm{~d}$ after inoculation. The evaluation of disease severity was based on a scale of notes as follows: $0.05,0.50,1.0,2.0,4.0,8.0,16.0,32.0$ and $67.20 \%$ of Ramularia leaf spot (Aquino et al., 2008b). The means per plant were used to calculate the area under the disease progress curve (AUDPC) (Shaner and Finney, 1977; Madden et al., 2007). The experiment was a completely randomized design with three replicates that each consisted of 5 pots with two plants.

\subsection{Integrated management of Ramularia leaf spot with cotton genotypes and a chemical fungicide}

The genotypes CNPA MT 2009-1381, CNPA GO 2007-419, BRS 293, BRS 372, CNPA GO 2008-1265 and FMT 701 were sown in Primavera do Leste, Mato Grosso State, São Desiderio, Bahia State, and Santa Helena de Goiás, Goiás State, for the 2011-2012 crop season. The experiments were performed twice in Primavera do Leste, with seeds sown for both a first and a second season. The treatment plots were sprayed with the fungicide Tetraconazole (Emerald ${ }^{\mathrm{R}}$ - FMC) at the rate of $0.5 \mathrm{~L} \mathrm{ha}^{-1}$ and were compared with untreated plots. The plants were sprayed with the fungicide 25,40 , $55,70,90,105$ and $120 \mathrm{~d}$ after emergence (DAE). $\mathrm{A} \mathrm{CO}_{2}$ pressurized backpack sprayer was used for spray the fungicide, with a two and half meter long bar and a five spray nozzles type double fan TJ 110.02, spaced at $50 \mathrm{~cm}$ (Herbicat, Catanduva, SP). The disease severity was assessed every two weeks, following Aquino et al. (2008b), and these results were used to calculate the AUDPC. The plots contained five- $5 \mathrm{~m}$ rows spaced $0.9 \mathrm{~m}$ apart. The experiment was arranged in a randomized block design with three replicates. The disease severity was estimated for 50 plants from each of the two central rows of each plot.

\subsection{Integrated management of Ramularia leaf spot with cotton genotypes, a chemical fungicide and Trichoderma asperellum}

Based on the results of the experiments described above, the genotypes BRS 293 and BRS 372 were cultivated in Sapezal, Mato Grosso State, in the 2012-2013 crop season. The treatments were either the fungicide Tetraconazole $\left(\right.$ Emerald $^{\mathrm{R}}$ ) at the rate of $0.5 \mathrm{~L} \mathrm{ha}^{-1}$ or the biocontrol agent T. asperellum (Quality WG Laboratório Farroupilha) at the rate of $0.1 \mathrm{~kg} \mathrm{ha}^{-1}$, and treated plots were compared with untreated plots. The plants were sprayed with the chemical or biofungicide 25, 40, 55, 70, 90, 105 and 120 DAE. The same sprayer describes before was used to spray the products. The disease severity was assessed 40, 55, 70, 90, 105, 120 and 135 DAE. To evaluate disease severity and calculate the AUDPC, the identical methodology was used as described previously. The plots and the experimental design were also identical to those described above.

\subsection{Statistical analyses}

The design of each experiment was a randomized block, which was repeated three times. Data for disease severity were examined using analysis of variance (ANOVA), and treatment means were compared with Tukey's tests $(P<0.05)$.

\section{Results}

\subsection{Assessment of cotton genotypes for Ramularia leaf spot management}

Interaction was detected between cotton genotypes and Ramularia isolates $(P<0.05)$. The genotypes LD CV 03, BRS 336, IAC 08-2031, IPR Jataí and IMA CD 03-1661 were the most susceptible to both isolates, with AUDPC values between 385.9 and 541.8 when inoculated with isolate IMA 244 and between 257.7 and 508.2 for isolate IMA 237 (Table 1). The genotypes IMA CD 05-8276 and CNPA GO 2007-419 had higher resistance to $R$. areola strains IMA 237 and IMA 244 (Table 1) than that of the other genotypes. The AUDPC values for IMA CD 05-8276 were 5.2 and 11.5 when inoculated with strains IMA 237 and IMA 244, respectively. For the genotype CNPA GO 2007-419, the AUDPC values were 13.2 and 17.8, respectively, when inoculated with these two Ramularia strains.

\subsection{Integrated management of Ramularia leaf spot with cotton genotypes and a chemical fungicide}

In the assay performed in São Desidério, the genotype CNPA GO 2008-1265, untreated with the fungicide, had the lowest severity rating when compared with that of the other genotypes (Table 2). 
Table 1

Area under the disease progress curve of Ramularia leaf spot in cotton genotypes inoculated with Ramularia areola isolates IMA 244 or IMA 237 in screen house.

\begin{tabular}{lll}
\hline Genotype & IMA 244 & IMA 237 \\
\hline LD CV 12 & $181.8 \mathrm{gB}$ & $221.4 \mathrm{deA}$ \\
CNPA GO 2006-174 & $155.9 \mathrm{gA}$ & $116.7 \mathrm{hB}$ \\
FM 993 & $193.4 \mathrm{gA}$ & $179.5 \mathrm{fgA}$ \\
IAC 08/90 & $214.1 \mathrm{fgA}$ & $200.4 \mathrm{efA}$ \\
Nuopal & $242.8 \mathrm{efA}$ & $221.6 \mathrm{deA}$ \\
PRGOA 03-231-04 & $184.4 \mathrm{fgB}$ & $252.2 \mathrm{cdA}$ \\
DP 604 BG & $277.7 \mathrm{deA}$ & $252.7 \mathrm{cdA}$ \\
FMT 709 & $28.1 \mathrm{iB}$ & $41.3 \mathrm{iA}$ \\
FM 910 & $95.5 \mathrm{hB}$ & $214.0 \mathrm{eA}$ \\
BRS 2080 & $332.6 \mathrm{cdA}$ & $162.3 \mathrm{gB}$ \\
IMA CD 05-8276 & $11.5 \mathrm{iA}$ & $5.2 \mathrm{jB}$ \\
CNPA GO 2007-419 & $17.8 \mathrm{iA}$ & $13.2 \mathrm{ijB}$ \\
IPR Jataí & $541.8 \mathrm{aA}$ & $380.3 \mathrm{bB}$ \\
LD CV 03 & $480.3 \mathrm{bA}$ & $508.2 \mathrm{aA}$ \\
BRS 336 & $385.9 \mathrm{cA}$ & $366.1 \mathrm{bA}$ \\
IAC 08-2031 & $539.2 \mathrm{aA}$ & $487.3 \mathrm{aB}$ \\
IMA CD 03-1661 & $523.6 \mathrm{abA}$ & $257.7 \mathrm{cB}$ \\
FMT 705 & $22.3 \mathrm{iA}$ & $148 \mathrm{ijB}$ \\
CV (\%) & 9.17 & 5.6 \\
\hline
\end{tabular}

Mean values with the same lowercase letters in the columns and the same uppercase letters in the line are not significantly different according to Tukey's test $(P<0.05)$

Table 2

Area under the disease progress curve (AUDPC) of Ramularia leaf spot in cotton genotypes treated or untreated with the chemical fungicide* in São Desiderio, Bahia State and in Santa Helena de Goiás, Goiás State, in field conditions (2011/2012 crop season).

\begin{tabular}{lll}
\hline São Desiderio & & \\
\hline Genotype & AUDPC & \\
\cline { 2 - 3 } & Treated & Untreated \\
\hline CNPA MT 2009-1381 & $55.5 \mathrm{aA}$ & $58.2 \mathrm{abA}$ \\
CNPA GO 2007-419 & $20.7 \mathrm{bA}$ & $67.5 \mathrm{aA}$ \\
BRS 293 & $15.8 \mathrm{bB}$ & $83.0 \mathrm{aA}$ \\
BRS 372 & $14.4 \mathrm{bA}$ & $39.6 \mathrm{abA}$ \\
CNPA GO 2008-1265 & $15.6 \mathrm{bA}$ & $11.4 \mathrm{bA}$ \\
FMT 701 & $15.8 \mathrm{bB}$ & $63.2 \mathrm{aA}$ \\
Average & 22.98 & 53.81 \\
Santa Helena de Goiás & & \\
CNPA MT 2009-1381 & $37.3 \mathrm{cB}$ & $100.3 \mathrm{cA}$ \\
CNPA GO 2007-419 & $17.5 \mathrm{cA}$ & $12.8 \mathrm{cA}$ \\
BRS 293 & $697.7 \mathrm{aB}$ & $1082.7 \mathrm{aA}$ \\
BRS 372 & $21.0 \mathrm{cA}$ & $18.7 \mathrm{cA}$ \\
CNPA GO 2008-1265 & $37.3 \mathrm{cA}$ & $53.7 \mathrm{cA}$ \\
FMT 701 & $394.3 \mathrm{bB}$ & $627.7 \mathrm{bA}$ \\
Average & 200.86 & 315.97 \\
\hline
\end{tabular}

Mean values with the same lowercase letters in the columns and the same uppercase letters in the line are not significantly different according to Tukey's test $(P<0.05)$. *Fungicide: Tetraconazole (Emerald - FMC at the rate of $0.5 \mathrm{~L} \mathrm{ha}^{-1}$ ).

When plants treated with the fungicide were compared with those untreated for the different genotypes, only genotypes BRS 293 and FMT 701 responded significantly to fungicide application (Table 2).

In Santa Helena de Goiás, the genotypes CNPA GO 2007-419, BRS 372 and CNPA GO 2008-1265 had the lowest AUDPC values, and these genotypes were not significantly affected by treatment with tetraconazole. This response indicated that these genotypes were tolerant to the disease (Table 2). However, for genotypes BRS 293 and FMT 701, the disease severity was much higher and increased even more in untreated plants than in those treated with the fungicide.

In the trial performed in Primavera do Leste, only the disease severity of genotype BRS 372 was not significantly different between fungicide treated and untreated plots during the first season. The genotypes CNPA MT 2009-1381, CNPA GO 2007-419, CNPA GO
2008-1265, BRS 293 and FMT 701 had the lowest ratings of disease severity when treated with the fungicide (Table 3). Therefore, fungicide application in combination with tolerant germplasm usually contributed to a reduction in the severity of the disease. However, without the fungicide, significantly higher values of AUDPC were observed with the genotypes BRS 293 and FMT 701. At this site, when the experiment was repeated for a second season, for the genotypes CNPA MT 2009-1381, CNPA GO 2007-419, BRS 372 and CNPA GO 2008-1265, no significant differences were detected in disease severity between the plants treated and untreated with the fungicide (Table 3). The genotype CNPA GO 20081265 had lowest AUDPC values in both treated and untreated plots, whereas the highest disease severities were observed for genotypes BRS 293 and FMT 701, with AUDPC values that varied from 2305.6 to 1777.3 in untreated plots.

\subsection{Integrated management of Ramularia leaf spot with cotton genotypes, a chemical fungicide and Trichoderma asperellum}

Based on the results described above, selected two were genotypes for this study: one susceptible to Ramularia leaf spot, BRS 293, and one resistant to the disease, BRS 372 (Tables 2 and 3). Based on analysis of the AUDPC values, the interaction genotype $x$ treatment was significant $(P<0.05)$. Moreover, the applications of the chemical fungicide and $T$. asperellum reduced the AUDPC values as compared with those in untreated plots, but the reduction in the severity of the disease with the fungicide was higher than that with Trichoderma (Fig. 1). Additionally, the severity of the disease was significantly different between genotypes, with the genotype BRS 372 more resistant to Ramularia leaf spot (Fig. 1). When the fungicide or T. asperellum was sprayed, the both AUDPC values decreased significantly. For genotype BRS 372, no significant effect of either chemical or biological control was observed on disease severity (Fig. 1). However, for BRS 293, the chemical fungicide and biocontrol agent significantly reduced the severity of the disease (Table 4, Fig. 1). Therefore, we verified that the severity of this disease could be reduced using varieties tolerant or resistant to Ramularia leaf spot in combination with another control method, such as biological control or a chemical fungicide. The low severity of the disease in variety BRS 372 did not allow for that large

Table 3

Area under the disease progress curve (AUDPC) of Ramularia leaf spot in cotton genotypes treated and untreated with the chemical fungicide* in Primavera do Leste Mato Grosso State (2011/2012 first and second seasons), in field conditions.

\begin{tabular}{lll}
\hline First season 2011/2012 & & \\
\hline Genotype & AUDPC & \\
\cline { 2 - 3 } & Treated & Untreated \\
\hline CNPA MT 2009-1381 & $67.2 \mathrm{cB}$ & $209.4 \mathrm{cA}$ \\
CNPA GO 2007-419 & $87.2 \mathrm{cB}$ & $397.2 \mathrm{cA}$ \\
BRS 293 & $949.5 \mathrm{aB}$ & $3203.5 \mathrm{aA}$ \\
BRS 372 & $88.3 \mathrm{cA}$ & $132.3 \mathrm{cA}$ \\
CNPA GO 2008-1265 & $43.4 \mathrm{cB}$ & $182.1 \mathrm{cA}$ \\
FMT 701 & $685.8 \mathrm{bB}$ & $2550.3 \mathrm{bA}$ \\
Average & 320.23 & 1112.46 \\
Second season 2011/2012 & & \\
CNPA MT 2009-1381 & $45.7 \mathrm{cdA}$ & $112.1 \mathrm{cA}$ \\
CNPA GO 2007-419 & $86.5 \mathrm{bA}$ & $123.9 \mathrm{cA}$ \\
BRS 293 & $974.5 \mathrm{aB}$ & $2305.6 \mathrm{aA}$ \\
BRS 372 & $81.1 \mathrm{bcA}$ & $86.3 \mathrm{cA}$ \\
CNPA GO 2008-1265 & $37.4 \mathrm{dA}$ & $82.2 \mathrm{cA}$ \\
FMT 701 & $990.3 \mathrm{aB}$ & $1777.3 \mathrm{bA}$ \\
Average & 369.26 & 747.89 \\
\hline
\end{tabular}

Mean values with the same lowercase letters in the columns and the same uppercase letters in the line are not significantly different according to Tukey's test $(P<0.05)$. *Fungicide: Tetraconazole (Emerald - FMC at the rate of $0.5 \mathrm{~L} \mathrm{ha}^{-1}$ ). 


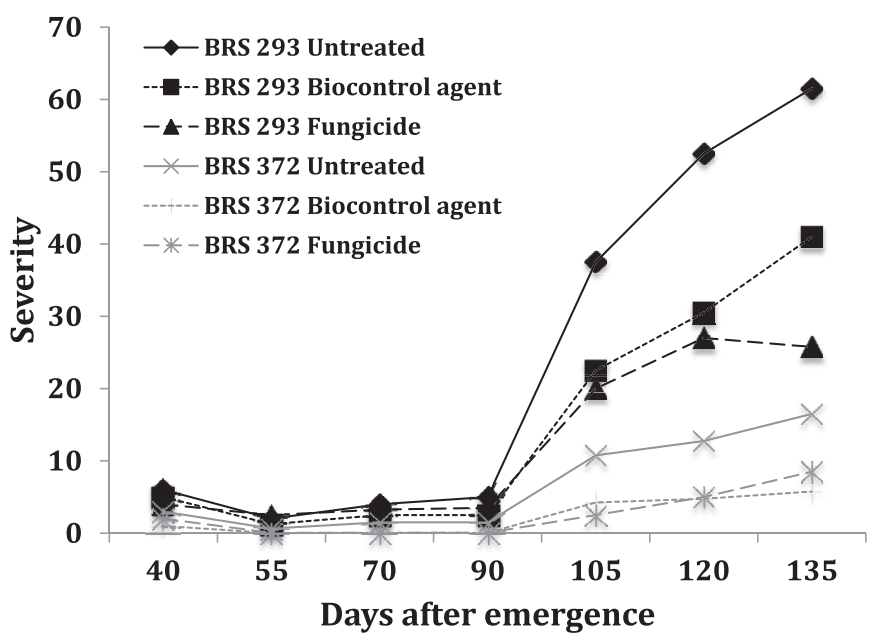

Fig. 1. Severity of Ramularia leaf spot on cotton treated and untreated with a biocontrol agent (Trichoderma asperellum-Quality WG - Laboratório Farroupilha) or treated and untreated with the chemical fungicide (Tetraconazole - Emerald, FMC) in Sapezal, Mato Grosso State, in field conditions (2012/2013 crop season). The severity was evaluated every two weeks, according on a scale of notes $(0.05,0.5,1.0,2.0,4.0$, 8.0, 16.0, 32.0 and $67.2 \%$ of Ramularia leaf spot) (Aquino et al., 2008b). $1=40,2=55$, $3=70,4=90,5=105,6=120$, and $7=135$ days after emergence.

Table 4

Area under the disease progress curve (AUDPC) of Ramularia leaf spot and fiber yield $\left(\mathrm{kg} \mathrm{plot}^{-1}\right)$ for cotton genotypes treated and untreated with the chemical fungicide or Trichoderma asperellum in Sapezal, Mato Grosso State, in field conditions (2012/ 2013 crop season).

\begin{tabular}{llllll}
\hline \multirow{2}{*}{ Treatment } & \multicolumn{2}{l}{ AUDPC } & & \multicolumn{2}{l}{ Fiber yield $\left(\mathrm{kg} \mathrm{plot}^{-1}\right)$} \\
\cline { 2 - 3 } & BRS 293 & BRS 372 & & BRS 293 & BRS 372 \\
\hline Untreated & $2322.2 \mathrm{aA}$ & $157.4 \mathrm{aB}$ & & $2.83 \mathrm{aB}$ & $3.92 \mathrm{aA}$ \\
Trichoderma* & $1806.2 \mathrm{bA}$ & $136.7 \mathrm{bB}$ & & $2.55 \mathrm{aB}$ & $3.64 \mathrm{aA}$ \\
Tetraconazole** & $1307 \mathrm{cA}$ & $66.8 \mathrm{cB}$ & & $2.99 \mathrm{aB}$ & $3.79 \mathrm{aA}$ \\
CV & 7.3 & & & 6.6 &
\end{tabular}

Mean values with the same lowercase letters in the columns and the same uppercase letters in the line are not significantly different according to Tukey's test $(P<0.05)$. *T. asperellum (Quality WG- Laboratório Farroupilha) at the rate of $0.1 \mathrm{~kg} \mathrm{ha}^{-1}$. **Emerald - FMC at the rate of $0.5 \mathrm{~L} \mathrm{ha}^{-1}$.

differences between treatments but still significant effects attributable to treatments with the fungicide or T. asperellum were observed (Table 4). However, for variety BRS 293, tetraconazole and T. asperellum spray decreased the AUDPC values by $43.7 \%$ and $22.2 \%$, respectively. While for fiber yield no significant differences were observed between the sprayed products and the control. The production of cultivar BRS 372 was $0.8-1.09 \mathrm{~kg} / \mathrm{plot}$ more than that of BRS 293, depending on the treatment (Table 4).

\section{Discussion}

Several authors have described the resistance and susceptibility of cotton to Ramularia leaf spot (Lima et al., 2010; Cia et al., 2008, 2014). In this study, were observed significant interactions between genotype and chemical fungicide and biofungicide treatments. Thus, based on our data, to reduce the severity of Ramularia leaf spot, the disease must be managed using tolerant or resistant varieties in association with another control method, such as biological control or a chemical fungicide.

An interaction between genotypes and Ramularia isolates was also observed in this study (Table 1), which is consistent with the results of several authors who also found interactions between cotton genotypes and isolates of Ramularia. Rathaiah (1976) suggested that the aggressiveness of $R$. areola isolates is variable, and Cia et al. (2013) observed variability in the pathogen from two different regions in Brazil. As observed by Pezenti et al. (2013), the genotypes CNPA BA-2003-2059 and FMT 02102996 were susceptible when inoculated with isolates $13.2,17.5$ and 58.4 of $R$. areola; however, these genotypes showed resistance when inoculated with the other isolates. In this study, the genotypend FMT 709 was resistant to two Ramularia isolates (IMA 244 and IMA 237) and that the genotypes BRS 336 and IAC 082031 were susceptibles (Table 1). Cia et al. $(2008,2014)$ observed that these three genotypes (i.e., IAC 08 2031, FMT 709, and BRS 336) were resistant. Therefore, as these results indicate, it is important to examine several isolates of $R$. aureola in the selection of germplasm (Girotto et al., 2013). Cia et al. (2014) highlight the potential risk of using susceptible genotypes in environments favorable to this disease.

For all the genotypes evaluated (CNPA MT 2009-1381, CNPA GO 2007-419, BRS 293, BRS 372, CNPA GO 2008-1265 and FMT 701) in the three regions, the importance of the chemical fungicide to control the disease was demonstrated (Tables 2 and 3). Disease severity was always lower in plots sprayed with tetraconazole than in those untreated, and for susceptible varieties, the difference in AUDPC values was more evident. However, for resistant varieties, although the disease was less severe in the plots treated with the fungicide, generally, the difference was not statistically significant (Tables 2 and 3). These results are consistent with those observed by Suassuna and Coutinho (2007) and Aquino et al. (2008a), with these authors recognizing the importance of chemical control to manage this disease.

In the assays we made to evaluate the integrated management of Ramularia leaf spot with cotton genotypes (BRS 293-susceptible; BRS 372-resistant), a chemical fungicide and T. asperellum, the chemical fungicide and Trichoderma significantly reduced the AUDPC values for both genotypes. However, the chemical fungicide was more effective than T. asperellum in controlling the disease, which was unexpected because the Trichoderma isolate used in this study is recommended for control of soilborne plant pathogens. However, we must consider that Trichoderma isolates have different mechanisms of action (Hermosa et al., 2012). This report is possibly the first in Brazil to demonstrate the efficiency of $T$. asperellum under field conditions for the control of Ramularia leaf spot.

In conclusion, integrated management, with an emphasis on the strategies of adopting resistant cotton varieties and spraying fungicides and biocontrol agents such as T. asperellum, is desirable for efficient control of Ramularia leaf spot on cotton.

\section{Acknowledgements}

Juliano C. Silva and Wagner Bettiol acknowledge Conselho Nacional de Desenvolvimento Científico e Tecnológico - CNPq for the scholarship and productivity fellowship, respectively. The authors acknowledge Edivaldo Cia (IAC) to provide of cotton seeds.

\section{References}

Aquino, L.A., Berger, P.G., Rodrigues, F.A., Zambolim, L., Ogoshi, F., Miranda, L.M., Lélis, M.M., 2008a. Controle alternativo da mancha de Ramularia do algodoeiro. Summa Phytopathol. 34, 131-136.

Aquino, L.A., Berger, P.G., Rodrigues, F.A., Zambolim, L., Hernandez, J.F.R., Miranda, L.M., 2008b. Elaboração e validação de escala diagramática para a quantificação da mancha de ramularia do algodoeiro. Summa Phytopathol. 34, $361-363$.

Aurangabadkar, J.H., Shukla, V.N., Wangikar, P.D., 1981. Reaction of some cotton varieties against grey mildew caused by Ramularia areola. Indian Phytopathol. 34, 244.

Bell, A.A., 1981. Areolate mildew. In: Watkins, G.M. (Ed.), Compendium of Cotton Diseases. The American Phytopathological Society, St Paul, p. 87.

Bettiol, W., 2011. Biopesticide use and research in Brazil. Outlooks Pest Manag. 22. 
$280-283$.

Bettiol, W., Maffia, L.A., Castro, M.L.M.P., 2014. Control biológico de enfermedades de plantas en Brasil. In: Bettiol, W., Rivera, M.C., Mondino, P., Montealegre, J.R. Colmenárez, Y.C. (Eds.), Control biológico de enfermedades de plantas en América Latina y el Caribe. Universidad de la Republica, Montevideo, pp. 91-138.

Cia, E., Fuzatto, G.M., Kondo, J.I., Sabino, N.P., Galbieri, R., Lüders, R., Carvalho, L.H., Ito, M.F., Erismann, N.M., Chiavegato, E., Bolonhesi, D., Foltran, D.E., Kasai, F.S. Bortoletto, N., 2008. Comportamento de genótipos de algodoeiro no Estado de São Paulo: produtividade, resistência a doenças e qualidade de fibra. Ciên. Rural. 38, 326-331.

Cia, E., Fuzatto, M.G., Martins, A.L., Michelotto, M.D., Almeida, W.P., Oliveira, A.P, 2009. Reação de genótipos de algodoeiro à incidência da mancha de Ramularia em condições naturais de infestação. In: Congresso Brasileiro do Algodão, 7. 2009, Foz do Iguaçu. Anais. EMBRAPA/Algodão, Campina Grande, pp. 1452-1455, 2009. 1 CDROM.

Cia, E., Fuzatto, M.G., Kondo, J.I., Ohl, G.A., Galbieri, R., 2013. Reação de genótipos de algodoeiro à mancha de Ramularia em diferentes épocas e ambientes. Summa Phytopathol. 39, 193-197.

Cia, E., Fuzatto, M.G., Almeida, W.P., Kondo, J.I., Ito, M.F., Dias, F.L.F., 2014. Reação de genótipos de algodoeiro à mancha-da-alternária. Summa Phytopathol. 40, $81-83$.

Duarte, R.P., Juliatti, F.C., Freitas, P.T., 2007. Genótipos, fungicidas e Trichoderma viride no controle da mancha de ramulária, ferrugem e podridão de maças, efeito na produtividade do algodoeiro. Congresso Brasileiro do Algodão, 2007. Available at: http://www.cnpa.embrapa.br/produtos/algodao/publicacoes/cba6/ trabalhos/Fitopatologia/Trabalho\%20F17.pdf (Accessed 05.2014).

Freitas, P.T., Juliatti, F.C., Duarte, R.P., 2007. Fungicidas e o fungo Trichoderma viride no controle da Mancha de ramularia, ferrugem e podridão de maçãs do algodoeiro, efeitos na produtividade e qualidade de fibra. Congresso Brasileiro do Algodão, pp. 1-7. Article number F22, Available at: http://www.cnpa.embrapa. br/produtos/algodao/publicacoes/cba6/trabalhos/Fitopatologia/Trabalho\% 20F22.pdf (Accessed 05.2014).

Girotto, L., Marangoni, M.S., Matos, J.N., Galbieri, R., Almeida, W.P., Mehta, Y.R., 2013. Identification of phenotypic and genotypic variability among the isolates of Ramularia areola of Brazilian cotton. Am. J. Plant Sci. 4, 1893-1898.

Harman, G.E., 2006. Overview of mechanisms and uses of Trichoderma spp. Phytopathology 96, 190-194.
Harman, G.E., Howell, C.R., Viterbo, A., Chet, I., Lorito, M., 2004. Trichoderma species opportunistic, avirulent plant symbionts. Nat. Rev. Microbiol. 2, 43-56. http:// dx.doi.org/10.1038/nrmicro797.

Hermosa, R., Viterbo, A., Chet, I., Monte, E., 2012. Plant-beneficial effects of Trichoderma and of its genes. Microbiology 158, 17-25.

Lima, L.L., Barreto, M., Scaloppi, E.A.G., 2010. Reação de cultivares de algodoeiro a Ramularia areola. Summa Phytopathol. 36, 57-60.

Lorito, M., Woo, S.L., Harman, G.E., Monte, E., 2010. Translational research on Trichoderma: from 'omics to the field. Annu. Rev. Phytopathol. 48, 1-23.

Madden, L.V., Hughes, G., van den Boschi, F., 2007. The Study of Plant Disease Epidemics. The American Phytopathological Society, St. Paul, p. 432.

Mukewar, P.M., Mayee, C.D., 2001. Grey mildew immune cotton germplasm lines registered. Indian Phytopathol. 54, 141.

Mukewar, P.M., Raj, S., Singh, V.V., Anap, G.R., 1995. Screening of tree cotton (Gossypium arboreum) germplasm to grey mildew caused by Ramularia areola. Indian J. Agr. Sci. 65, 298-300.

Pérez, E., Belén Rubio, M., Cardoza, R.E., Gutiérrez, S., Bettiol, W., Monte, E. Hermosa, R., 2015. The importance of chorismate mutase in the biocontro potential of Trichoderma parareesei. Front. Microbiol 1-14. http://dx.doi.org/ 10.3389/fmicb.2015.01181, 6 Article 1181.

Pezenti, L.F., Barbosa, J., Vieira, M.A., Marangoni, M.S., Volponil, J., Almeida, W.P. Galbieri, R., Mehta, Y.R., 2013. Phenotypic variability among isolates of Ramularia areola from Brazilian cotton. Trop. Plant Pathol. 38, 329-331.

Rathaiah, Y., 1976. Reaction of cotton species and cultivars to four isolates of Ramularia areola. Phytopathology 66, 1007-1009.

Shaner, G., Finney, R.E., 1977. The effect of nitrogen fertilization on the expression of slow-mildewing resistance in knox wheat. Phytopathology 67, 1051-1056.

Suassuna, N.D., Coutinho, W.M., 2007. Manejo das principais doenças do algodoeiro no cerrado brasileiro. In: Freire, E.C. (Ed.), Algodão No Cerrado Do Brasil. Gráfica Talento, Brasilia, pp. 479-521.

Woo, S.L., Scala, F., Ruocco, M., Lorito, M., 2006. The molecular biology of the interactions between Trichoderma spp., phytopathogenic fungi, and plants. Phytopathology 96, 181-185.

Zandoná, C., Novaes, T.G. Nunes, M.P. Almeida, W.P. Aguiar, P.H., Morello, C.L. Shuster, I., Mehta, Y.R., 2012. Mechanism of resistance and presence of different resistance genes to Ramularia areola in two cotton genotypes. Trop. Plant Pathol. 37, 175-178. 